\title{
A Study on the Effect of Product Market Competition, Monetary Compensation of Executives on Cost Stickiness
}

\author{
Le Liu ${ }^{1,}$, Chaoyang Zhou ${ }^{1, b}$ \\ ${ }^{1}$ School of management, Wuhan University of Technology, Wuhan 430070, China \\ aliule20131102@163.com, b179740616@qq.com
}

Keywords: cost stickiness; monetary compensation of executives; product market competition

\begin{abstract}
Based on the related data from 2008 to 2016 in China's A stock market, this paper empirically studies the relationship between product market competition, monetary compensation of executives and cost stickiness. The results show that the monetary compensation of executives plays a positive role in restraining cost stickiness, and the competition degree of product market has a constraint on the subjective decision-making behavior of executives. The conclusion is helpful for executives to fully grasp the competitive situation of product market, establish a reasonable executive compensation system and weaken the cost stickiness.
\end{abstract}

\section{Introduction}

Traditional cost habits divide costs into fixed costs and variable costs. Within a certain range, the fixed costs do not change with the change of business and the variable costs vary proportionate to the volume of business. However, this theory has been overturned by empirical data. In 2003, Anderson, Banker and Janakiraman found that the increase in sales and management costs was higher than the decrease in operating income, that is the theory of cost stickiness. In 2004, on the basis of Anderson's research, Subramaniam and Weidenmier found that the marketing cost, the sales cost and the total cost were sticky, and the concept of "Cost Stickiness" was proposed formally.

For the cause of the formation of cost stickiness, Sun Zheng and Liu Hao (2004) summarized the early research results as "contractual view", "efficiency view" and "management opportunism view". In the view of contract, enterprises often sign a long-term contract with some units or people to keep normal operation. Long-term contracts have high adjustment costs, which means that even in the market recession, the enterprise will not modify it in the short term. The "efficiency view" holds that managers can only be effective in adjusting expenses and expenditures when the economic business is continuously changing. At the same time, due to the limited capabilities of low-level managers, it is impossible to make timely and effective adjustments to the cost based on the dynamic changes in the situation, and cost stickiness may also occur. Management opportunism view believes that managers will substantially increase the cost and expand the resources they control when the volume of 
business is rising. When the volume of business falls, managers are not willing to reduce their own salaries, nor are they willing to reduce the resources they control, thus producing a cost stickiness.

In addition, some scholars have studied the impact of corporate governance mechanism on cost stickiness. For example, Liu Wu (2006), through an empirical study of the financial data and corporate governance data of Chinese listed companies from 1999 to 2005, found that the corporate governance structure has a significant impact on the cost stickiness of listed companies. Wan Shou Yi and Wang Hongjun (2011) studied 740 Shanghai and Shenzhen A stock listed companies and found that the separation of the chairman and the general manager and the independence of the board can reduce the cost stickiness, and the larger the board, the more will sticky the cost will be. From the perspective of behavioral finance, the study of Dai Zili and Luo Xuan (2016) shows that the existence of board governance can indirectly weaken the cost stickiness of the enterprise by restricting the overly self-interest behavior of the managers.

The research on the influencing factors of cost stickiness at home and abroad is mostly from the perspective of board governance, which is the core mechanism of corporate governance. This is the internal governance mechanism of the company, and few scholars have studied whether the company's external governance mechanism have direct or indirect effects on the cost stickiness at present.

This paper takes the listed companies of China's A - share manufacturing industry as the research object, empirically analyzes the influence of executive monetary compensation on the cost stickiness, and then studies the impact of the product market competition, which is the corporate external governance, on the relationship between the executive monetary compensation and the cost stickiness.

\section{Literature Review and Research Hypothesis}

\subsection{The existence of cost stickiness}

As an important part of the company's business management, cost is not only influenced by the amount of business, but also controlled by the management. This kind of agency problem caused by the inconsistency of the target makes the cost sticky universal. The empirical study of Wang Man (2014) shows that the total cost of China's listed companies is not only sticky, but also the various cost types are mostly sticky. Bi Xiuling (2015) made an empirical study on mining, construction and agriculture, forestry and animal husbandry. The results showed that the cost stickiness existed in the three industries, and there was no cost stickiness being overestimated. Wei Lijie et al. (2014) selected 14 listed shipping companies in Shanghai and Shenzhen stock exchanges for empirical research and found that the shipping industry has a sticky cost and is affected by financial crisis and capital intensity. According to this, the following assumption is put forward:

H1: There is cost stickiness in Chinese A-share listed companies.

\subsection{Monetary compensation of executives and cost stickiness}

Salary incentives, as the most direct incentive method that affects the interests of managers, are widely used in enterprises. Shareholders generally use corporate profitability indicators as an important basis for measuring and assessing senior executives' performance. According to Chen Donghua et al. (2005), China does not have a complete managerial market. A large part of the self-interest behavior of senior executives is due to the lack of executive monetary compensation. According to the optimal contract theory, companies should constantly improve the executive 
compensation and provide full incentive, until the incremental cost of doing this is greater than the incremental profit generated by the incentive. Executive compensation, as an incentive policy related to the interests of managers, directly affects managers' motivation and efficiency. Based on this, the following assumption is put forward:

H2: Executive monetary compensation helps to reduce cost stickiness.

\subsection{The impact of the product market competition on the relationship between the executive monetary compensation and cost stickiness}

In a perfectly competitive market, competition is adequate without any hindrance and interference, and resources can flow freely. In this case, information is complete. However, the actual market can not achieve a complete competition, but the market competition can effectively transfer information and reduce the agency problems caused by information asymmetry, thus reducing the agency cost. In addition, in a highly competitive market, enterprises will not be faced with the risk of being eliminated by the market only if they improve their operational efficiency from all aspects. Therefore, the fierce competition in product market also helps to constrain the opportunist behavior of managers, and promotes managers to improve their management. According to this, the following two hypotheses are proposed:

H3a: the higher degree of product market competition, the more it can inhibit the influence of monetary compensation of executives on the cost stickiness.

H3b: the degree of product market competition can not significantly affect the relationship between monetary compensation of executives and cost stickiness.

\section{Research and Design}

\subsection{Sample data and data sources}

In this paper, we need to make use of the financial statement data of the current year and one year behind, and the new accounting standards of China began to be implemented since January 1, 2007. In order to eliminate the influence of the record and measurement difference in economic matters before and after the implementation of the new accounting standards, the Chinese A - share listed manufacturing companies from 2008 to 2016 were selected as the initial samples. According to the following standards, the initial samples are eliminated: (1) ST and *ST listed companies; (2) listed companies with serious missing data; (3) to avoid the influence of extreme values, the data of each variable are handled by 5\% Winsorize. Finally, 2011 sample data are obtained.

The data of the paper comes from the CSMAR database, and then, preprocessed and analyzed through Excel 2013 and SPSS22.0.

\subsection{Variable design}

Explained variable. Compared with the operating cost, the confirmation of sales cost and management cost is more flexible and easier to be manipulated by the management. Therefore, this paper uses the sum of sales expenses and management costs in the profit list (hereinafter referred to as SG\&A) as the cost change index, the uses natural logarithm of the change rate of the sales and management costs (Ln $\triangle \mathrm{SG} \& A$ ) as the explained variable.

Explanatory variables. There are four explanatory variables in this study including dummy variables.

(1) the rate of change of business income ( $\operatorname{Ln} \Delta$ Sales). This year's operating income is compared 
with the natural logarithm of the change in operating income last year.

(2) virtual variable (Dec). Compared with the previous year, the operating income decreased by $\mathrm{Dec}=1$ this year, and the operating income increased by $\mathrm{Dec}=0$ this year.

(3) monetary compensation of executives (Ln (Rewards)). Using the sum of the top three monetary compensation executives to represent executive pay level, the natural logarithm is taken as the explanatory variable.

(4) there is no recognized index to measure the product market competition. This paper uses the monopoly rent (PMC) as the measurement index of the product market competition in the industry, and the income of PMC=[tax depreciation amortization - (long term Liabilities + shareholders equity) * weighted average capital cost)/ sales volume. The weighted average cost of capital is the sum of the long-term loan interest rate over the past five years and the current inflation rate. The higher the monopoly rent is, the lower the product market competition is.

Control variables. Based on the previous research results, five indicators were selected as control variables.

(1) the scale of the company (Ln (Assets)). It is measured by the natural logarithm of the total assets.

(2) capital density (AI). It is measured by the ratio of total assets to the ratio of business only.

(3) labor intensity (EI). It is measured by the ratio of the number of employees to the business income.

(4) the debt ratio (Debt). It is measured by the ratio of total liabilities to the total assets.

(5) macro-economic growth rate (GDP). This year's GDP is measured compared with last year's growth rate.

The explained variable, explanatory variables and control variables above are specified in Table 1:

Table 1 Variable description

\begin{tabular}{|c|c|c|c|}
\hline type & name & code & definition \\
\hline \multirow[t]{3}{*}{$\begin{array}{l}\text { Explained } \\
\text { variable }\end{array}$} & $\begin{array}{l}\text { the change rate of sales and } \\
\text { management costs }\end{array}$ & $\operatorname{Ln} \triangle S G \& A$ & $\begin{array}{l}\text { Ln(The sum of sales and management costs of the } \\
\text { year / Last year's sales and management costs) }\end{array}$ \\
\hline & $\begin{array}{l}\text { the rate of change of } \\
\text { business income }\end{array}$ & Ln\Sales & Ln(Operating income of the year / previous year) \\
\hline & & & $\begin{array}{c}\text { Business income in this year was lower than last } \\
\text { year,Dec }=1\end{array}$ \\
\hline \multirow{6}{*}{$\begin{array}{l}\text { Explanator } \\
\text { y variables }\end{array}$} & virtual varıable & Dec & $\begin{array}{l}\text { Business income in this year was higher than last } \\
\text { year,Dec }=0\end{array}$ \\
\hline & $\begin{array}{l}\text { monetary compensation of } \\
\text { executives }\end{array}$ & Ln(Rewards) & $\begin{array}{l}\text { Ln(Top three monetary remuneration of } \\
\text { executives) }\end{array}$ \\
\hline & & & [tax depreciation amortization - (long term \\
\hline & product market competition & PMC & $\begin{array}{l}\text { Liabilities + shareholders equity) * weighted } \\
\text { average capital cost) / sales volume }\end{array}$ \\
\hline & the scale of the company & Ln(Assets) & Ln(total assets) \\
\hline & capital density & $A I$ & Total assets / business income \\
\hline \multirow{3}{*}{$\begin{array}{c}\text { Control } \\
\text { variables }\end{array}$} & labor intensity & $E I$ & Number of employees / business income \\
\hline & the debt ratio & Debt & Total liabilities / total assets \\
\hline & $\begin{array}{l}\text { macro economic growth } \\
\text { rate }\end{array}$ & $G D P$ & (GDP - last year GDP) / last year GDP \\
\hline
\end{tabular}

There are three models. 
(1) test on the existence of cost stickiness of Listed Companies in China's manufacturing industry (hypothesis H1)

Referring to previous studies on cost stickiness, this paper establishes a regression model (1):

$L \mathrm{n} \Delta S G \& A=\beta_{0}+\beta_{1} L \mathrm{n} \Delta$ Sales $+\beta_{2} L \mathrm{n} \Delta$ Sales $\times$ Dec $+\beta_{3}$

In the model (1), if the operating income increased by $1 \%$, the SG\&A increased by $1 \%$; if the operating income decreased by $1 \%$, the SG\&A decreased $\left(\beta_{1}+\beta_{2}\right) \%$. If $\beta_{2}<0$, it shows that the decrease of SG\& A is less than the increase of SG\&A when the operating income is increased, which shows the existence of the phenomenon of cost stickiness. And the size of $\beta_{2}$ measures the degree of cost stickiness. The smaller the $\beta_{2}$, the greater the cost stickiness.

(2) a test of the effect of monetary compensation of executives on cost stickiness (hypothesis H2)

On the basis of the model (1), we add monetary compensation of executives and control variables to establish a model (2):

$\operatorname{Ln} \Delta S G \& A=\beta_{0}+\beta_{1} L \mathrm{n} \Delta$ Sales $+\beta_{2} L \mathrm{n} \Delta$ Sales $\times$ Dec $+\beta_{3} L \mathrm{n} \Delta$ Sales $\times$ Ln $($ Rewards $) \times$ Dec

$+\beta_{4} \operatorname{Ln} \Delta$ Sales $\times \operatorname{Ln}($ Assets $) \times$ Dec $+\beta_{5} \operatorname{Ln} \Delta$ Sales $\times A I \times \operatorname{Dec}+\beta_{6} L \mathrm{n} \Delta$ Sales $\times E I \times$ Dec

$+\beta_{7} L \mathrm{n} \Delta$ Sales $\times$ Debt $\times$ Dec $+\beta_{8} L \mathrm{n} \Delta$ Sales $\times G D P \times D e c+\beta_{9}$

In the same way, in the model (2), if $\beta_{3}<0$, it shows that the monetary compensation of executives can promote the cost stickiness; if $\beta_{3}>0$, it shows that the monetary compensation of executives has a inhibitory effect on the cost stickiness.

(3) a test on the impact of product market competition on the relationship between monetary compensation of executives and cost stickiness (hypothesis H3)

The PMC variable is introduced to measure the degree of the product market competition, and the effect of product market competition on the relationship between monetary compensation of executives and cost stickiness is studied with the help of interactive terms, get the model (3):

Ln $\triangle S G \& A=\beta_{0}+\beta_{1} L \mathrm{n} \Delta$ Sales $+\beta_{2} L \mathrm{n} \Delta$ Sales $\times$ Dec $+\beta_{3} L \mathrm{n} \Delta$ Sales $\times$ Ln (Rewards $) \times$ Dec

$+\beta_{4} \operatorname{Ln} \Delta$ Sales $\times \operatorname{Ln}($ Rewards $) \times P M C \times \operatorname{Dec}+\beta_{5} L \mathrm{n} \Delta$ Sales $\times \operatorname{Ln}($ Assets $) \times$ Dec

$+\beta_{6} L \mathrm{n} \Delta$ Sales $\times A I \times D e c+\beta_{7} L \mathrm{n} \Delta$ Sales $\times E I \times D e c+\beta_{8} L \mathrm{n} \Delta$ Sales $\times$ Debt $\times$ Dec

$+\beta_{9} L \mathrm{n} \triangle$ Sales $\times G D P \times D e c+\beta_{10}$

We can test the impact of product market competition on the relationship between monetary compensation of executives and cost stickiness by comparing $\beta_{4}$. If $\beta_{4}$ is significantly negative, it shows that in the case of low product market competition (higher PMC), the impact of monetary compensation of executives on cost stickiness increases; if $\beta_{4}$ is significantly positive, the influence of monetary compensation of executives on cost stickiness is weakened under the condition of higher product market competition (lower PMC).

\section{Empirical Results and Analysis}

Table 2 lists the empirical results of hypothesis $\mathrm{H} 1, \mathrm{H} 2$ and $\mathrm{H} 3$.

From the standardized $\beta$ coefficient of model (1), we can see that the estimated value of $\beta_{1}$ is 0.681 , and the estimated value of $\beta_{2}$ is -0.145 , which is related to the significant level of $1 \%$. The sales revenue increased by $1 \%$, SG\&A increased by $0.681 \%$, but when the operating income decreased by $1 \%$, the SG\&A only decreased by $0.536 \%$. That is, the decrease of SG\&A at the time of decrease in 
operating income is less than the increase of SG\&A at the increase of operating income, indicating that there is indeed cost stickiness in China's A-listed manufacturing manufacturing companies, hypothesis $\mathrm{H} 1$ is verified.

From the standardized $\beta$ coefficient of model (2), we can see that when we add monetary compensation of executives and each control variable, the estimated value of $\beta_{1}$ is 0.679 , the estimated value of $\beta_{2}$ is -0.873 , and the positive and negative coefficients are consistent with the verification results of model (1). It shows that after adding other explanatory variables and control variables, China's A-share manufacturing listed companies still have a strong cost stickiness. The estimated value of $\beta_{3}$ is 0.367 , which is positively correlated with the explanatory variable at the $5 \%$ level of significance. This indicates that the monetary compensation level of executives can suppress the cost stickiness phenomenon, thus hypothesis H2 is verified. When the level of monetary compensation of executives is low, the goals of senior executives are prone to disagreement with the pursuit of shareholder interests, induce moral hazard, and are not conducive to the long-term development of the company. Senior executives' monetary remuneration can be effectively remunerated by senior executives in the short term, and can motivate senior executives to make objective judgments and responses to changes in the company's operating environment in the short term, especially the control of costs and expenses.

From the standardized $\beta$ coefficient of model (3), it can be found that when the interaction of product market competition and executive monetary compensation is added, the normalized coefficient $\beta_{3}$ of the interaction term is 0.073 , and it is also related to the significant level of $1 \%$, indicating that the product market competition is related to the cost stickiness of the executive monetary salary and the product market. The higher the degree of field competition, the weaker the impact of monetary compensation on cost stickiness. The regression result supports the hypothesiss $\mathrm{H} 3 \mathrm{a}$ and negates the hypothesiss H3b. It shows that product market competition as a company's external governance mechanism can restrain senior executives' self-interest behavior. In the fierce competition environment of the company's product market, the executives are more inclined to take the overall situation as the heavy, from the cost management and other aspects to cope with the fierce competition, the cost of sales and management costs are controlled in time, and the stickiness of cost is weakened.

Table 2 Multivariate regression results for cost stickiness

\begin{tabular}{|c|c|c|c|c|c|c|}
\hline \multirow[b]{2}{*}{ variables } & \multicolumn{2}{|c|}{ Model (1) } & \multicolumn{2}{|c|}{ Model (2) } & \multicolumn{2}{|c|}{ Model (3) } \\
\hline & $\begin{array}{c}\text { Standardization } \\
\text { coefficient }\end{array}$ & Significant & $\begin{array}{l}\text { Standardization } \\
\text { coefficient }\end{array}$ & Significant & $\begin{array}{c}\text { Standardization } \\
\text { coefficient }\end{array}$ & Significant \\
\hline Ln $\Delta$ Sales & 0.681 & 0.000 & 0.679 & 0.000 & 0.676 & 0.000 \\
\hline Ln $\Delta$ Sales $\times$ Dec & -0.145 & 0.000 & -0.873 & 0.000 & -0.866 & 0.000 \\
\hline $\begin{array}{c}\text { Ln } \Delta \text { Sales } \\
\times \text { Ln }(\text { Rewards }) \times \text { Dec }\end{array}$ & - & - & 0.367 & 0.011 & 0.133 & 0.036 \\
\hline $\begin{array}{c}\text { Ln } \Delta \text { Sales } \\
\times \text { Ln(Assets }) \times \text { Dec }\end{array}$ & - & - & 0.337 & 0.013 & 0.589 & 0.000 \\
\hline Ln $\Delta$ Sales $\times$ AI $\times$ Dec & - & - & -0.075 & 0.000 & -0.133 & 0.000 \\
\hline Ln $\Delta$ Sales $\times$ EI $\times$ Dec & - & - & 0.086 & 0.000 & 0.092 & 0.000 \\
\hline Ln $\Delta$ Sales $\times$ Debt $\times$ Dec & - & - & -0.056 & 0.000 & -0.059 & 0.000 \\
\hline $\mathrm{Ln} \Delta$ Sales $\times \mathrm{GDP} \times \mathrm{Dec}$ & - & - & 0.056 & 0.017 & 0.043 & 0.027 \\
\hline $\begin{array}{c}\text { Ln } \Delta \text { Sales } \\
\times \text { Ln }(\text { Rewards }) \times \mathrm{PMC} \times \text { Dec }\end{array}$ & - & - & - & - & 0.073 & 0.000 \\
\hline
\end{tabular}




\section{Conclusion}

There are the research conclusions of this paper: (1) There is cost stickiness in the listed companies of A share manufacturing industry in China. When the operating income declines, the decrease in sales and management costs is less than the increase in sales and management costs when the operating income rises. It shows that the sales cost and management cost are easily influenced and controlled by human beings, and then the cost stickiness is produced. (2) The level of monetary compensation of executives can inhibit the stickiness of cost, that is, the higher the level of e monetary compensation of executives, the more effective the executives can control the sales and management cost when the operating income falls. It shows that under the incentive and constraint of the salary, the interests of executives are more consistent with the enterprise goals, which will help to reduce the cost stickiness. (3) Product market competition, as the external governance mechanism of the company, can weaken the impact of executive compensation on cost stickiness. Because the product market competition can restrict the behavior of executives, so that managers will be based on maximizing corporate profits when making cost decisions.

Faced with the fact that the level of market competition is not sufficient and the behavior of managers is not fully rational, we should take measures from the internal and external of the enterprise to reduce the cost stickiness:

(1) Improve the quality of managers. Because of the incentive effect of salary, the phenomenon of cost stickiness can be significantly improved, which indicates that the management efficiency and cost management efficiency of the senior executives of A - share manufacturing companies are influenced by their own salary level. Therefore, the managers can improve their quality by strengthening their own culture and professional ethics to make scientific and rational decisions. This can not only improve the short-term performance of the enterprise, but also improve the long-term value of the enterprise.

(2) Improve the internal management of the company and strengthen the supervision. We can learn from the advanced western management methods, improve the standards for the identification of internal control defects in the company, encourage enterprises to open internal control defects, improve the internal governance structure of the company, strengthen the monitoring of the board of directors and the board of supervisors, and control the power of the executives reasonably.

(3) Create a fair market competition environment. The government should establish a fully competitive market economy mechanism to truly reflect the market information and enhance the transparency of the product market information, restrain the management behavior of the executives, and encourage the executives to make objective and rational decisions. In addition, we should break the entry barriers of some monopolistic industries and promote the full competitiveness of the product market.

\section{References}

[1] Banker R.D., Johnston H.H. An empirical study of cost drivers in the US airline industry[J]. Accounting Review, 1993: 576-601.

[2] Anderson M. C., Banker R. D., Janakiraman S. N. Areselling, general, and administrative costs “sticky ”? [J]. Journal of Accounting Research,2003,41(1):47-63.

[3] Balakrishnan R., Peterson M., Soder-strom N. Does capacity utilizationaffect the stickiness of costs? [J]Ac-count. Audit. Finance,2004,19(3):283- 299.

[4] Sun Hao, Liu Hao. Research on the cost "stickiness" behavior of listed companies in China [J]. Economic Research, 2004, (12): 26-34+84.

[5] Jiang Wei, Hu Yuming. Cost Stickiness of Enterprises: Literature Review and Outlook [J]. Accounting Research, 2011(9):74-79.

[6] Liu Wu. " stickiness " behavior of corporate expenses: An empirical study based on industry differences [J]. China 
Industrial Economy, 2006 (12): 105-112.

[7] Wan Shouyi, Wang Hongjun. Management self-interest, board governance and cost stickiness: empirical evidence from listed companies in China's manufacturing industry[J]. Economics and Management, 2011, 25(03):26-32.

[8] Daizi Dai, Xuan Luo. Empirical Study on the Governance of Board of Directors and Cost Stickiness: Based on the Managerial Overconfidence of the Mediator Effect [J]. Friends of Accounting, 2016, (12):59-63.

[9] Wang Man, Liu Shui, Shi Rui. Empirical analysis of Chinese cost stickiness based on industry differences and cost types [J]. Journal of Dalian Maritime University: Social Science Edition, 2014, 13(5): 36-40.

[10] Bi Xiuling, Tan Xuefeng. Empirical Study of Cost Stickiness Overhang in Different Industry in China [J]. Friends of Accounting, 2015, (09): 33-36.

[11] Wei Lijie, Xiao Kangyuan. Cost Stickiness Research: Empirical Evidence from Listed Companies in Shipping Industry, Transportation Finance and Accounting [J]. 2014(4).

[12] Liu Ping, He Wei. Research on transportation cost stickiness of listed companies in transportation industry [J] Railway Transport and Economy, 2015, (8): 6-10.

[13] Chen Donghua, Chen Xinyuan, Wan Hualin. Salary control and on-the-job consumption in state-owned enterprises [J]. Economic Research, 2005 (2): 92-101.

[14] Holmstrom B. Moral Hazard in Teams[J]. Bell Journal of Economics,1982,13: 324-340. 